and contradictions in the sentence at the stage of executing the sentence]. Entrepreneurship, economy and law, no. 10, pp. 165-168.

3. Dilna, Z. F. (2013). Sumnivy ta protyrichchia, shcho vynykaiut pry vykonanni vyroku, ta poriadok ikh vyrishennia [Doubts and contradictions that arise while executing the sentence and the procedure for resolving them]. Bulletin of the Academy of Advocacy of Ukraine, no 1(26), pp. 143-148.

\title{
PECULIARITIES OF CONDUCTING COVERT INVESTIGATIVE (SEARCH) ACTIONS DURING THE INVESTIGATION OF CRIMES RELATED TO THE ABUSE OF POWER OR OFFICIAL POSITION
}

\author{
Nataliia Cherniak $^{1}$ \\ Vita Pervii $^{2}$
}

DOI: https://doi.org/10.30525/978-9934-26-002-5-35

Part II of Art. 19 of the Constitution of Ukraine declared that state authorities and local self-government bodies, their officials are obliged to act only on the basis within the powers and in the manner provided by the Constitution and laws of Ukraine. This provision of the Basic Law indicates that officials authorized to perform the functions of public authorities or local self-government are obliged to act in their daily activities only as it is directly allowed by the law. Any deviation from this principle is offence of law, one of the most dangerous of which is the abuse of power or official position, criminal liability for which is provided by Art. 364 of the Criminal Code of Ukraine. This crime is qualified as corruption by the Criminal Law. Law enforcement is entrusted with the implementation of state policy in the field of national security, prevention of crime and corruption.

The institute of investigative (search) actions has always been in the center of attention of scientists and practitioners. Close attention to this institute is due to the fact that investigative (search) actions are the main means of information support of the evidentiary process in criminal proceedings.

The Criminal Procedure Code of Ukraine (hereinafter - the CPC of Ukraine) provides for the institution of CISA, which is a kind of investigative (search) actions, information about the fact and methods of which are not

\footnotetext{
${ }^{1}$ Dnipropetrovsk State University of Internal Affairs, Ukraine

${ }^{2}$ Dnipropetrovsk State University of Internal Affairs, Ukraine
} 
subject to disclosure, except for the cases provided by the CPC of Ukraine (Part 1 of Article 246) [1].

The main direction of using the results of covert investigative (search) actions (hereinafter - CISA) in the investigation of crimes related to abuse of power or official position, as pointed out by M.V. Bagriy and V.V. Lutsyk, is to obtain evidence and its further use to prove the guilt of the person (people) in committing the crime. This direction fully corresponds to the purpose of such actions and reveals the potential of these criminal procedure means.

The use of the results of the CISA is also possible in the investigation of other criminal proceedings. The use of the results of the CISA to make certain procedural decisions implies the right or obligation of the person conducting the pre-trial investigation, to make a decision in accordance with current legislation [2, p. 153].

V. Y. Tatsiy and Y. M. Groshevyi state that investigative actions are characterized by certain features that distinguish them from other procedural actions, they specifically have a cognitive focus on obtaining, recording or verifying evidence; they significantly violate the rights and legitimate interests of individuals, and therefore some of them require the consent of the prosecutor or the permission of the investigating judge; the procedure for their implementation is enshrined in the criminal procedure law, as well as it is provided by public enforcement [3, p. 365].

In addition to the above, the defining feature of CISA is their nonobviousness, secrecy from authorities who do not participate in them, including those who are not related to CISA, but primarily to the entities in respect of which they are conducted [4, p. 7]. In accordance with Part 2 of Art. 246 of the CPC of Ukraine, the application of CISA is possible only in respect of serious and especially serious crimes, if it is not possible to obtain the information about the crimes and the person who committed them in another way [1]. Thus, taking the above mentioned into consideration, it should be stated that CISA are the actions aimed at obtaining (collecting) evidence or verification of evidence already obtained in a particular criminal proceeding, information about the fact and methods of which are not subject to disclosure, except as provided by the law.

Considering the special procedure for conducting the CISA M.V. Danshin notes that the CPC of Ukraine is supplemented by means of «operational and investigative nature» [5, p. 23]. Unfortunately, this does not reveal how to understand the means of this nature. In terms of cognitive methods of obtaining information, CISA and EOA have much in common. Both during criminal procedural and enforcement operations activities, information is obtained through material reflection during the inspection of things, as well as from people who are in contact with them. 
Analyzing this question, A.A. Poltavsky notes that «enforctment operations activities were never procedural activities, and accordingly the information obtained through them, for example, about a person involved in a crime, had to be «legalized» in the manner provided by the actual criminal procedural law» [6, p. 108].

Indeed, the detection of crimes is provided by two types of activity, such criminal procedure and enforcement operational actions. Each of them is carried out by cognitive means. Despite the similarity of cognitive capabilities in obtaining information, they are governed by different laws. The grounds and procedure for conducting CISA are regulated by the norms of the Criminal Procedure Code of Ukraine, and enforcement operative measures are regulated by the Law «Enforcement Operations Act» of Ukraine [7].

Thus, it is not entirely accurate to note the consolidation of operational and investigative measures in the CPC of Ukraine. CISA is a type of investigative (search) actions as a means of forming judicial evidence in criminal proceedings in the investigation of crimes related to abuse of power or official position. By their legal nature, they are criminal procedural actions, the procedural form of which differs from the procedure of enforcement operative measures. CISA are allowed only during specific criminal proceedings. Most of them are conducted with the permission of the investigating judge at the request of the prosecutor or an investigator agreed with the prosecutor.

Exceptions are control over the commission of a crime (Part 4 of Article 246 and Part 7 of Article 271 of the CPC of Ukraine) and the performance of a special task to disclose the criminal activities of an organized group or criminal organization (Part 2 of Article 272 of the CPC of Ukraine) [1].

When examining CISA used in the investigation of crimes related to abuse of power or official position, we should distinguish such actions as: audio and video monitoring of a person (Article 260 of the CPC of Ukraine); imposition of seizure of correspondence (Article 261 of the CPC of Ukraine); inspection and excision of correspondence (Article 262 of the CPC of Ukraine); removal of information from transport and telecommunication networks (Article 263 of the CPC of Ukraine); removal of information from electronic information systems (Article 264 of the CPC of Ukraine); control over the commission of a crime (Article 271 of the CPC of Ukraine) [7].

Thus, crimes committed in the sphere of official activity are not detected in full. Only individual, isolated facts of criminal activity fall into the field of view of law enforcement officers, and it is not possible to trace and identify all schemes of illegal activity and the mechanism of achieving the criminal goal. In our opinion, the application of the CISA to this group of crimes should be based not only on the norms of national legislation, but also on the 
norms of international legal acts regulating the issues of interaction and legal assistance between countries.

\section{References:}

1. Criminal Procedure Code of Ukraine: Law of Ukraine of April 13, 2012, Verkhovna Rada of Ukraine. URL: http://zakon3.rada.gov.ua/laws/show/4 651-17

2. Bagriy M.V., Lutsyk V.V. Covert investigative (search) actions in criminal proceedings: monograph. Lviv, 2014. $307 \mathrm{p}$.

3. Criminal Proceedings: a textbook / Yu. M. Groshevy, V. Ya. Tatsiy, etc.; for order. V. Ya. Tatsiya, Yu. M. Groshevoy, O.V. Kaplina, O.G. Shilo. Kharkiv: Pravo, 2013. $824 \mathrm{p}$.

4. Covert investigative (search) actions and the use of the results of operational and investigative activities in criminal proceedings: teaching practice / C.C. Kudinov and others. Kharkiv: Oberig, 2013. 344 p.

5. Danshin M.V. The practical significance of establishing interdisciplinary links between criminology and the sciences of the criminal law cycle. Criminalistics and forensics ecspertise: interdepartmental scientific and methodical weed. Kiev: Ministry of Justice of Ukraine, 2014. Issue 59. P. 19-26.

6. Poltavsky AA Problematic issues of legal regulation of the functioning of the system of forensic registration by the Criminal Procedure Code of Ukraine: ways to improve. Criminalistics and forensics ecspertise: interdepartmental scientific and methodical weed. Kiev: Ministry of Justice of Ukraine, 2014. Issue 59. P. 107-114.

7. Enforcement operations activities: Law of Ukraine of 18.02.1992 № 2135-XII. Verkhovna Rada of Ukraine. URL: zakon.rada.gov.ua/go/2135-12 